\title{
SUSTAINABILITY IN THE PORTUGUESE FASHION ACCESSORY \& FOOTWEAR INDUSTRY (CASE STUDIES)
}

\section{Patrícia AZAMBUJA, António MARQUES*, Ana BROEGA}

University of Minho, Campus de Azurém -4600-065 Guimarães, Portugal, pati_azambuja@hotmail.com, adinis@det. uminho.pt, cbroega@det.uminho.pt

Received: 20.11.2018

Accepted: 30.01 .2019

https://doi.org/10.24264/Ifj.19.1.5

SUSTAINABILITY IN THE PORTUGUESE FASHION ACCESSORY \& FOOTWEAR INDUSTRY (CASE STUDIES)

ABSTRACT. The Portuguese footwear has the second most expensive pair of shoes produced in Europe (Italy has the most expensive), it is the only country in the world that produces more footwear than it consumes. The main environmental impacts caused by this sector are at residues containing chromium in its composition, such as leather flaps and leather powder, which are difficult materials to degrade by the environment and therefore highly polluting. Being a thriving industry is also one of the firsts to have concerns with the issue of sustainability, emerging already some cases of good practice in the framework of sustainable strategies. This paper uses the case study research strategy of footwear brands and Portuguese accessories. The field study shows that the most commonly adopted sustainability principles are the choice of less polluting materials, less aggressive tanning leather, or even alternative materials. Products created with greater cultural value and in a more traditional way, towards the adoption of a slow fashion in the footwear sector.

KEY WORDS: Sustainability, fashion footwear, upcycling.

SUSTENABILITATEA ÎN INDUSTRIA ACCESORIILOR DE MODĂ ȘI ÎN INDUSTRIA DE ÎNCĂLȚĂMINTE DIN PORTUGALIA (STUDII DE CAZ)

REZUMAT. Industria de încălțăminte portugheză este pe locul doi în Europa privind prețul pentru o pereche de pantofi (Italia este pe locul întâi) și este singura țară din lume care produce mai multă încălțăminte decât consumă. Principalele efecte asupra mediului cauzate de acest sector sunt datorate deșeurilor care conțin crom, cum ar fi resturile și pulberea de piele, materiale care se degradează greu în mediul înconjurător și, prin urmare, sunt foarte poluante. Fiind o industrie înfloritoare este, de asemenea, una dintre primele care au preocupări privind sustenabilitatea, existând deja câteva cazuri de bune practici în cadrul strategiilor sustenabile. Această lucrare utilizează metoda de cercetare prin studii de caz ale unor branduri portugheze de încălțăminte și accesorii. Studiul de teren arată că principiile de sustenabilitate adoptate cel mai frecvent sunt alegerea materialelor mai puțin poluante, pielea tăbăcită mai puțin agresiv sau chiar materialele alternative. Produsele sunt create cu o valoare culturală mai mare și într-un mod mai tradițional, mergând spre adoptarea modei lente în sectorul încălțămintei.

CUVINTE CHEIE: sustenabilitate, încălțăminte de modă, upcycling.

DURABILITÉ DANS L'INDUSTRIE PORTUGAISE DE L'ACCESSOIRE DE LA MODE ET DE LA CHAUSSURE (ÉTUDES DE CAS)

RÉSUMÉ. L'industrie portugaise de la chaussure est classé deuxième en Europe en ce qui concerne le prix d'une paire de chaussures (I'Italie est la première) et c'est le seul pays au monde qui produit plus de chaussures qu'il n'en consomme. Les principaux effets environnementaux causés par ce secteur sont dus aux résidus contenant du chrome, tels que débris et poudre de peau, des matériaux difficiles à dégrader dans l'environnement et sont donc très polluants. Elle est une industrie florissante mais également l'une des premières à se préoccuper de la durabilité, certaines bonnes pratiques étant déjà en place dans les stratégies de durabilité. Cet article explore la méthode de recherche à travers des études de cas de marques portugaises de chaussures et accessoires. L'étude sur le terrain montre que les principes de durabilité les plus couramment adoptés consistent à choisir des matériaux moins polluants, du cuir tanné moins agressif, voire des matériaux alternatifs. Les produits sont créés avec une plus grande valeur culturelle et de manière plus traditionnelle, en allant vers l'adoption de la mode lente dans le secteur de la chaussure.

MOTS CLÉS: durabilité, chaussures de mode, upcycling.

*Correspondence to: António MARQUES, University of Minho, Campus de Azurém, 4800-058, Guimarães, Portugal, adinis@det.uminho.pt 


\section{INTRODUCTION}

The current commercial system is going through several modifications in attempting to solve or at least to relieve the problems from an unbridled production over the years. Numerous changes in the environment, including the greater scarcity of raw material resources, the observed climate changes, financial crises, and an increasingly uncertain future, have been collaborating for the companies to look for a way to reverse the situation by reviewing their actions and strategies of business and manufacturing for the future.

The moment lived is of great concern with the environment and issues related to the production processes, especially within the fashion world. It is becoming increasingly necessary to adopt a development model that minimizes environmental impacts. The accelerated ways of production are today one of the biggest reasons for the deterioration of the environment, which is the cause of the growing accumulation of industrial waste and immature discarded products.

Whenever a material results from a production left-over and has no longer valor after a process, is discarded by the industry and is then called industrial waste [1]. According to Sousa [2], "industries that use leather as a raw material (footwear, clothing, upholstery, bags, belts, etc.), about $15 \%$ of the raw materials put into operation are discarded as waste leather (leather flaps or scrap in semi-finished and finished)". These residues normally containing chromium in their composition, those are materials that are difficult to be degraded by the environment and therefore highly polluting, which can only be disposed of in landfills or in some cases for incineration (although with a risk of contamination). Among the major current challenges facing from the footwear and accessories industries is the search for an effective solution to first minimize these industrial waste, and then find efficient ways of recycling it in order to minimize the environmental impacts of these products. On the other hand, this sector, as well as all other fashion, has a strong competition with the entry of Asian countries into the world market with competitive prices and mass production. With all these factors, the footwear sector industry is increasingly concerned with the creation of a differentiated product of quality and the implementation of a system that contemplates the environmental issues, thus reducing the damage to the environment and at the same time creating a differential advantageous in this competitive market.

From a new reality compelled by environmental concerns, entrepreneurs and designers, driven by more conscious consumers, are concerned with finding viable solutions to the environmental problem of contamination and undue disposal of waste. In response, the shoe sector has been seeking to develop more sustainable products. Discarded waste is often a quality raw material that can be reinserted into the more artisanal production chain. Waste that is discarded, properly or unduly, in the environment is a concern and reuse is one of the most sustainable processes in the search for the valuation of discarded materials, studied by sustainable design [3].

Thus, designers are increasingly involved in the issue of sustainability, undertaking the study of the Product Life Cycle, seeking to satisfy an increasing concern in the development of sustainable products that involves not only the selection and use of materials but also the forms of construction involved and the disposal. When it comes to products developed from highly polluting raw materials, the study of waste generated is fundamental, and the designer plays an important role in the search for solutions for the reduction of industrial waste, and in the creation of alternatives for the reuse of these wastes [4].

Based on this context and seeking to know better the strategies of the footwear sector involving sustainable development, this paper studies the brands of the Portuguese footwear companies concerned and involved in sustainable projects. Thus, the main objective of this article is to study the case of footwear/ accessories brands in Portugal, to analyze the sustainability principles most commonly adopted by companies and to understand the reasons why the footwear sector is concerned with issues related to investment in sustainable products. 


\section{Footwear Industry in Portugal}

The Portuguese footwear business has the second most expensive pair of shoes in Europe behind only the Italian withal is a unique case in which it is the only country in the world that produces more footwear than it consumes [5]. This has the entire production chain, with a good knowledge of production, fashion, and design. According to the World Footwear Congress, held in May 2018, "the Portuguese footwear industry is innovative and strong performance in exportation." According to the same source, "more than $95 \%$ of its production is destined for external markets and that, it exported more than 80 million pairs of footwear in 2017". The Congress approached the theme "From-Fashion to Factory: a new technological age", and argues that the footwear industry in Portugal represents a model of competitiveness and one of the great examples of modernization and innovation in tradition [6].

According to APICCAPS (Portuguese Association of Manufacturers of Footwear, Components and Leather Products founded in 1975 and headquartered in Porto), the Portuguese footwear industry has been growing more and more in the foreign market and is in the eighth consecutive year of international growth [7]. This growth is part of the goals contained in Footure 2020 - Strategic Plan of the Cluster of Portuguese Footwear. Among the actions included in this plan is also the search for sustainable and responsible development, this line of action aims at the development and dynamization of new social practices and methodologies in the areas of environment, energy, and certification. Its objectives are also to develop solutions to increase the efficiency in the use of raw materials, principles of footwear ecodesign, new processes of recycling of products and development of tools for the sustainable management of waste and by-products [8]. According to the same source, in the last decade more than 342 footwear brands were created in Portugal, data from the GAPI (Support Office for the Promotion of Industrial Property) of the Technological Center of Footwear of Portugal which demonstrates a new reality in the sector, a greater valorization of shoes collections, products and "Made in Portugal" as a brand.
These new brands are part of the priority of the strategic plan created by the sector, the "Footure 2020", which looks forward to a more modern industry focused on the future, combining the tradition of Portuguese footwear and technologies. This movement has been running since 2008 with the "Portuguese Shoes: Designed by the Future" campaign, in which companies/brands have focused mainly on the international market [8].

Through the 2014-2020 action plans, the footwear cluster strategy aims to consolidate Portugal's position as a "benchmark of the footwear industry worldwide, grounding the creativity and sophistication of products with a sustainable production base and highly competitive, based on knowledge and innovation". Following this proposed action plan, it can be said that the Portuguese footwear sector continues to be aligned with the principles of a "circular economy", with a concern for the reuse of resources and the use of more sustainable raw materials, while continuing technological innovation.

Portuguese companies have searched for technological intervention together with the adoption of increasingly sustainable measures. The sector has been reinventing itself and has been positioning itself in the foreign market through high standards of quality and environmental concern. This is reflected in the APICCAPS data, which states that in 2017, the value of exports totaled 2 billion euros (corresponding to 83 million pairs of shoes sold). These figures point to a new record for the eighth consecutive year of growth, with industry growth of more than 55\% since 2009 [8].

\section{Development of Sustainable Products}

By making an analysis on the environmental issue it is easily identified that the footwear industry is a highly polluting sector. This is due to the types of waste generated, many of them contaminated with heavy metals, being a big problem for the companies, the communities where they are inserted and for the environment in general. For these reasons, complying with tight Environmental Legislation in European is currently one of the greatest challenges for companies in the sector. However, the 
Portuguese companies in the sector have been dedicated to sustainability issues with great success, which has brought them benefits both in the management of their business and in the sustainability of the environment [9].

According to the Technology Center of Footwear of Portugal (CTCP), companies have searched for support in the implementation of an environmental management system as well as its certification. This implementation of an environmental management system and its ISO 14001 certification allows companies to reduce the environmental impact by reducing waste, which means reducing costs of their entire production process, to be more environmentally and economically efficient, to improve their reputation to their consumers, as well as the conquest of new markets and customers [10].

The Portuguese footwear cluster has invested more and more in R\&TD, currently around $8.2 \mathrm{M} €$ of investment aiming at the differentiation and diversification of products with the objective of supporting the added value of exporting capacity, which includes the creation of new Competitive business solutions in the areas of materials, components and accessories; shoe; manufacturing processes, logistics and business models. Within the FOOTURE 2020 strategic plan is the project called FAMEST-Footwear and advanced technologies of materials, equipment, and software, which involves 33 copromoters. Among the approaches are design, customization, additive manufacturing, industry 4.0, online sales, recycling and circular economy [11]. As it can be seen, the environmental issue is among the investments and strategies of the sector, giving focus to recycling and to the circular economy. The footwear sector in Portugal has invested heavily and is now considered a more sustainable industry, at the level of the productive processes and the level of the raw materials used and manufactured products, is also less carbon generator [11].

Focusing on environmental issues, CTCP has created the eco-label called Biocalce, this label serves to identify footwear that respects the environment during its manufacturing process this involves all phases, from design, when the material is chosen, to the way of manufacturing. Currently "more than $60 \%$ of the rubber soles used, which look like a rubber are made of thermoplastic and recyclable materials and the rubber when used whenever possible is recycled. The outer materials are also natural materials such as linen or cotton", explains Maria José Ferreira, director of the new materials unit at CTCP [12].

\section{CASE STUDY: PORTUGUESE FOOTWEAR BRANDS SEARCHING FOR SUSTAINABILITY}

The environment and sustainability are global concerns, brands are looking for strategies to solve problems with design as a great collaborator. The Portuguese footwear cluster has as action plans to search for better productivity, improved quality, innovation, and sustainability. In order to demonstrate these principles, Table 1 presents some cases of Portuguese footwear brands with success and in the sense of understanding the sustainable strategies adopted in the sector.

Table 1: Sustainable strategies adopted by Portuguese footwear brands

\begin{tabular}{|c|c|}
\hline Brands & Sustainable Strategies \\
\hline $\begin{array}{l}\text { Nae Vegan Shoes } \\
\text { www.nae-vegan.com }\end{array}$ & $\begin{array}{l}\text { Footwear with animal-friendly and vegan philosophy since } 2008 \text {. Use of natural and ecological } \\
\text { materials certified by OEKO-TEX. Concerns with design, style, and quality. All the manufacturing in } \\
\text { Portugal in places certified in environmental and social standings. A line of products made exclusively } \\
\text { from recycled plastic bottles and tires, another line of products made with pineapple fiber fibers } \\
\left(\text { Piñatex }^{+}\right) \text {. It is also the first world brand to develop footwear through the recycling of airbags. }\end{array}$ \\
\hline $\begin{array}{l}\text { MDMA Shoes } \\
\text { www.mdmashoes.com }\end{array}$ & $\begin{array}{l}\text { With the motto: "minimize damage MAXIMIZE ART", develops limited edition footwear lines, } \\
\text { from discarded domestic garments and industrial waste. It works in partnership with the } \\
\text { management of domestic and industrial waste companies. Uses rubber waste to the sole. }\end{array}$ \\
\hline $\begin{array}{l}\text { Balluta Shoes } \\
\text { https://balluta-shoes. } \\
\underline{\text { com }}\end{array}$ & $\begin{array}{l}\text { It uses traditional techniques and ecological materials (cork, textiles produced with European } \\
\text { certification), and quality philosophy (recycled polyamide and non-solvent) in order to guarantee } \\
\text { the quality of the product and reflect the brand's commitment to sustainability. The production } \\
\text { is handmade in family factories with the tradition that respect the rights and decent working } \\
\text { conditions of its employees. }\end{array}$ \\
\hline
\end{tabular}

+ Piñatex: fiber produced from pineapple leaves, food waste, produced in the Philippines by an English company working with local pineapple communities, with the aim of helping communities through decent jobs, fair pay and local economy increasing. 
Softwaves Green Edition

(from Comforsyst Company)

AsPortuguesas www.asportuguesas. shoes.com

Zouri www.zourishoes.com

Introduced in 2014 as a line of ecological footwear from the Comforsyst Portuguese company, whose main points is the comfort and the sustainability using only materials of natural origin such as natural fibers, cork, wood and "Leather BioNature". The "BioNature Leather" was developed for this shoe line in a project in partnership with the Portuguese tannery company ANC (António Nunes Carvalho) and the Faculty of Sciences of the New University of Lisbon (FCTUNL), the CTCP and the CTIC. The objective was to develop "biodegradable leathers" with the least possible impact on the environment $[13,14]$.

It develops sandals (flip-flops) in $100 \%$ natural material with low ecological impact (like the cork that is extracted without the need of cutting the tree). Its design is intended for surfers. Having social concerns the brand also has a project that involves supporting a social cause for each pair sold $€ 1$ reverts to Surf School created by Hawaiian surfer Garrett McManara in Nazareth and for helping orphaned children with this sport. The professional surfer is also the brand's new ambassador and will sign two collections a year titled "Everything is possible".

It arises from a dream of two friends to collaborate with the cleaning of the Atlantic Ocean. They decided to transform the bottles and rubbles of fishing nets left on the beaches and the result was the creation of the brand that each pair of slippers or sandals, incorporates between 80 to 100 grams of plastic which means about 6 plastic bottles. The brand does not use any animal product, it is a vegan company and seeks to develop organic products, ecological and with a fair trade policy. It also uses raw materials such as cork, recycled rubber, as Piñatex. The development of the soles that incorporate the plastic of the bottles was carried out in partnership with the University of Minho in Portugal and has already achieved the prize for Best Product Idea with Reutilization of Plastic Waste 2017. The company that owns the brand has a partnership with the City Council of Esposende in Portugal that organizes the action of cleaning the beach, in that action, it was collected in the last year about 1500 kilos of plastic that were milled and transformed into raw material for the manufacture of Zouri products. After collecting the plastic, it is transported and processed by Ecoibérica (a company specializing in the recycling of plastic waste) [15].

Subsequent the demonstrative presentation of some brands that are already committed to developing the products within a sustainable concept, it is presented the two case studies of Portuguese brands that were born as part of a sustainable philosophy, either from the environmental point of view, or socio-cultural, they are: the shoe and accessories company Marita Morena and the fashion accessory company Ideal \& Co.

\section{Case Study 1: "Marita Moreno"}

Created in 2008 by Designer Marita Setas, the main objective is to contribute to innovation in the creation and production of sustainable fashion objects, with the main focus being the valorization of Portuguese products and materials. It seeks the application of new technologies without leaving aside the values of crafts, culture and traditional methods of production. The products are created and produced in Portugal and commercialized abroad, contributing to the dissemination of quality products made in Portugal: "Made in Portugal" to the world. The products are developed from the north of Portugal but worked with artisans from all over the country.
The CEO and designer of the brand like to work on themes of Portuguese culture as the Azulejos (Portuguese ceramic tiles) and whenever possible with traditional crafts making, she is keen on knowing all the artisans with whom she works [16]. One of the most recent collections is called Azores (Fig. 1), it is produced in the Azores and uses sustainable and different materials such as cork and the traditional weaving of Azorean quilts. The brand also uses wood and cork on the platforms, leather with sustainable production (tanned without using chromium) and "bio-leather".

The brand works with 3 lines, the line of leathers (ecological tannage), the vegan line that uses materials such as polyurethane microfiber, cork, and textiles, and also the line upcycling (with materials leftovers from other collections). Except for microfiber, all materials used are of Portuguese origin. The Dali collection presents a series of products with asymmetrical lines inspired by Salvador Dali paintings, is part of the upcycling line, all made with reuse of materials leftovers from previous collections [17]. The creations presented by the brand have products with a contemporary design that value the quality of raw materials, the manufacturing 
and also the cultural and historical value that count and transport to the world, thus becoming a differentiated product capable of showing cultural and heritage values of Portuguese. The brand has created a line in which the products are made of fabric with leather details made with handcrafted white linen, and in contrast with vibrant and intense colors, referring to the typical of Portuguese ceramics tiles Azulejos (Fig. 1).
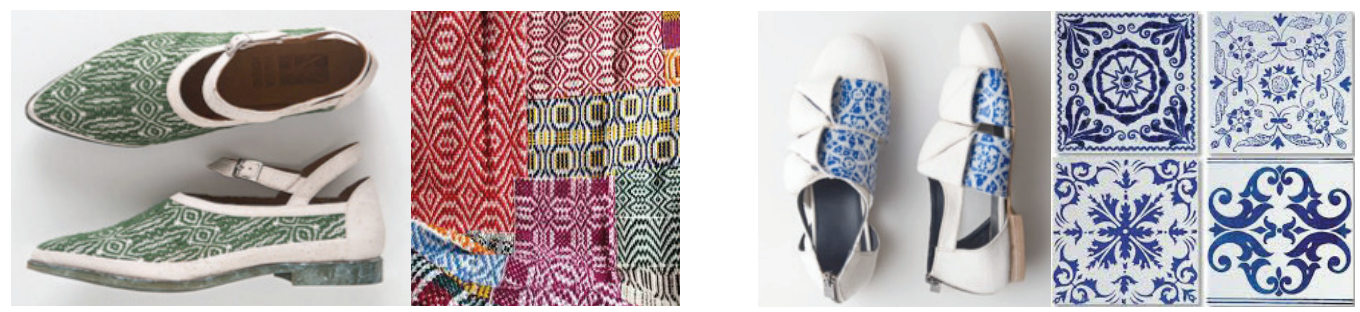

Figure 1. Collection Azores (Azores and quilts) | Artists \& Artisans Collection, (Portuguese Ceramic Tiles) Source: Marita Moreno, 2018

The brand Marita Moreno was born as a brand of design and apparel, with the objective of developing unique pieces through Portuguese weaving and embroidery, in a socio-cultural sustainability approach, however, it begins to develop design pieces and accessories with the production of bags and shoes. What never changed was the brand's constant search for developing products using elements of Portuguese heritage and culture as inspiration in order to spread Portuguese culture in the national and international markets. The brand believes that 3 factors are fundamental, ethics, transparency and social sustainability [17].

According to its CEO, "the concern with ethical and sustainability values has a social responsibility as the main factor, through work with great technical knowledge, allowing the improvement of local processes and knowledge, contributing to the valorization and to increase the quality of life of the involved people". Marita adds that the company also creates training and professional opportunities for underprivileged communities to ensure good working conditions, and "only works with the (her) brand, companies that do not exploit child labor and pay fair salaries with good working conditions" [16]. The production of the brand is made with certified and accredited craftsmen and produces about 100 pieces per model (all pieces are numbered) in order to have the minimum environmental impact avoiding excess production and waste of materials. The production uses natural materials such as wool, flax, cotton, cork, and some other natural fibers and also makes use of recycling of its materials taking advantage of every piece of material even the smallest [17].

\section{Case Study 2: IDEAL \& CO}

The company created in 2012 by designers Rute Vieira and José Lima was presented from the beginning by the slogan "Living Heritage". It was a way of honoring and prolonging the existence of a family heritage in which the leather tanning business was from the grandfather of Rute and served as inspiration for the creation of the brand [18]. As a result of this partnership linked to tradition and history comes the brand that develops bags, backpacks, covers for tablets and mobile phones, bicycle accessories, stationary for office among other handmade articles and signed by the craftsman who manufactures them (fig 2). The pieces are created in co-design by both designers and result in pieces with a unique and timeless design in a minimalist style and that seeks to preserve the knowledge of the artisans of the Serra d'Aire and Candeeiros Natural Park. The brand's mission is to create unique, quality models, respecting and preserving nature and past work from generation to generation of artisans [18]. Another characteristic of the brand is that most articles are intended for those who use bicycles as a means of transportation (Fig. 2). The relationship with the bicycle comes from the 

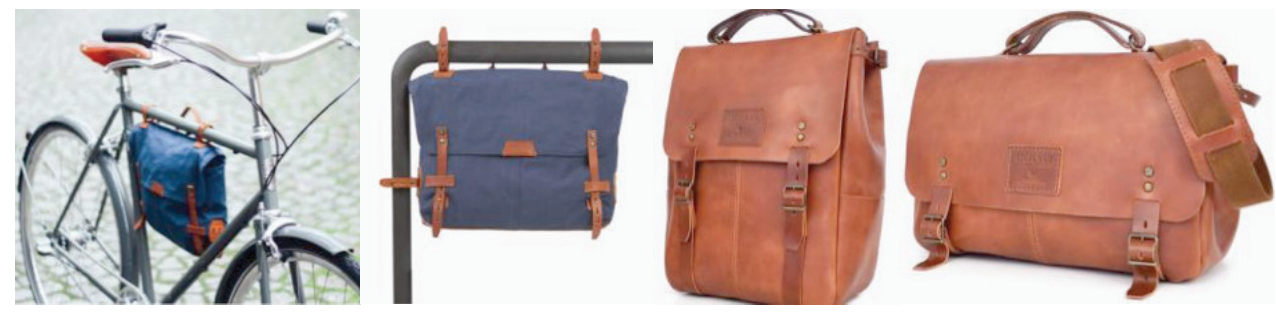

Figure 2. "Mira" Bicycle Frame | "Candeeiros" Backpacks | "Air Messenger" Bag. Source: Ideal \& Co, 2018

history of the brand, in which the grandfather of the designer of the brand (Rute), used this transportation to trade his leather business in 1935, and also due to the passion for bicycles shared by the designer of the brand José Lima.

Ideal \& Co aims to be a reflection of the Portuguese cultural heritage and the capital of Portuguese natural and human resources, using noble raw materials, transformed in an ecological and sustainable way, valuing the work of experienced craftsmen [19]. The brand based on sustainable concepts seeks for the product of quality and each stage is thought, from the origin of the raw material, the form of tanning, labor skills, the manual development of each piece, each stage of the process is thought searching for quality products and that represent something else for the customer and not just a simple accessory. The brand's pieces have history and the brand wants them to carry its history and its values and that they make their ones history being passed down through generations. One of its most emblematic pieces is the Candeeiros backpack (Fig. 2) highlighted by the English magazine Monocle, as it has already conquered markets such as Singapore, Hong Kong, the United Kingdom, Germany and Denmark [19].

The pieces are produced individually by the hands of experienced craftsmen and made using the best Portuguese leather, the leather is tanned with vegetable tannins from trees and dyed with natural dyes. As a result of this process, the vegetable tanned leather develops a pátine that gives the piece its special appearance and beauty, and the more the piece is used and exposed to natural elements, such as the sun, the more beautiful it becomes. This type of traditional tanning work is done by a few factories in Portugal, it is a very old technique, but the brand has opted for the vegetal way of tanning the leather because it is the most ecological form and also because this type of tanning transmits to the products a unique character, the pieces come to life and the use of the pieces will personalize them. In each article manually created by the artisans, the phrase "some things stay with you forever" is engraved just to say that they are timeless pieces that can be passed down from one generation to the next [18]. The company Ideal \& Co, at the same time as it intends to revive the traditional and non-polluting industry, also aims to stimulate the work of small workspaces and artisans who maintain the work in a traditional way. The brand search for to revitalize the artisans and workspaces in the Natural Park of Serra d'Aire and Candeeiros through the reintegration of different groups of artisans who worked alone or in small workshops (ateliers) and as a result of this integration an improvement in traditional production techniques [18].

\section{CONCLUSIONS}

The Industry, in general, is experiencing a need to create more environmentally friendly and sustainable solutions and products, but we must also reverse the scale of damage to the planet. The chemicals used to date that cause damage to the environment, excessive use of water in production, undue disposal of raw materials are some of the most important points in this new phase of production.

While these environmental issues are on 
the rise and are a worldwide concern we have the economic need to increase production, and this article refers in particular to the cluster of Portuguese footwear that is in full development. APICCAPS (Portuguese Association of Footwear, Components and Leather Products Manufacturers) has created the strategic plan for the Portuguese footwear cluster, Footure 2020, which together with CTCP (Centro Tecnológico de Footwear de Portugal) promotes actions for the development of the sector of the Portuguese footwear industry, also involving sustainability. One of the actions is the campaign to promote the image of Portuguese footwear Portuguese Shoes: Designed by the Future, which has helped companies to disseminate their image and increase the number of exports with quality and preferably committed to sustainability. Portuguese footwear is already seen as a highquality product and is increasingly investing in technology and image. Among the actions is the development of technological solutions that allow the developed product to have economic efficiency and at the same time the nobility of artisanal production.

The environmental issue is also very present, the entire production chain of footwear has focused on high standards of sustainability and social responsibility, contributing to the development goals of Portuguese society. In this way, the shoe cluster shares these objectives, promoting image, tradition, innovation, product quality, sustainability, and social responsibility. Among the fundamental values of the strategic plan of the shoe cluster is also the design as a differentiating factor in the sector.

Through the present study, it can be seen that there is an increasing number of new footwear brands created by young entrepreneurs with great concern for environmental issues. New brands with the intention of not only creating products but mainly making a difference, create products that do not exhaust natural resources and that help in the solution of the damages caused by the years of accelerated production without questioning raw materials and production methods. A generation of companies focused on the future, a great desire for internationalization, but without going over social and environmental values. There is a concern to follow the tradition of Portuguese footwear with the use of new materials, new components and new technologies for sustainable and responsible development, and often being able to reduce production costs. An appreciation of handmade products and respect for craftsmen through decent working conditions.

Among all the companies, it is verified that the principle of sustainability most commonly adopted was the recycling of both internal and external materials, recycling discarded material to create a new product with concern in design, comfort, social issues, and also in the use of raw materials, natural raw materials. Trademarks with a vegan philosophy, that is, they do not use any material of animal origin and no production process involving animal exploitation. These companies/brands adopted this philosophy in their products for personal, environmental and perceived a gap regarding the offer of this type of product in the sector

Within the studied companies in this cases studies, the brands Marita Moreno and Ideal \& Co, concerns follow the same line of thought. They look for more ethics productions, transparency, and sustainability. There is also the focus on social issues, concern not only with the environment, origin of raw materials, production methods, but also with the quality of life of the workers involved. Together with these factors, they search to present to the world what Portugal does better, exporting together with its design products of quality, the culture, and history of the country.

The concern with the production of a sustainable product besides collaborating with the preservation of the environment still presents another great advantage that is the added value to the product. By being part of these ecological and social causes, brands end up having more credibility and consequently 
having more visibility and gaining new markets. What we conclude for future productions is that products that use biodegradable raw materials, are sustainability-focused and have social causes involved will have a likely competitive advantage in the marketplace, and all Portuguese companies should be aware of this fact.

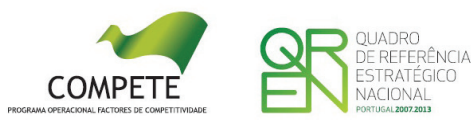

\section{REFERENCES}

1. Menegucci, F. et al., Resíduos têxteis: Análise sobre descarte e reaproveitamento nas indústrias de confecção, Proceedings of XI Congresso Nacional de Excelência em Gestão, 2015, [online] ISSN 1984-9354, available from: http://www.inovarse.org/sites/ default/files/T_15_325.pdf, accessed 201709-28.

2. Sousa, J.A.F., Reaproveitamento de resíduos sólidos classe 1 de couros em semiacabado e acabado de diferentes raças, 2010, [online] available from: http://www.bv.fapesp.br/ pt/bolsas/123701/ reaproveitamento-deresiduos-solidos-classe-1-de-couros-emsemiacabado-e-acabado-de-diferentesracas/, accessed 2018-07-2.

3. Oliveira, E.A.G. et al., Reuso de Resíduos Têxteis em Comunidades Artesanais do Agreste Pernambucano, Proceedings of $9^{\circ}$ Colóquio de Moda, 2013, Fortaleza, Brasil.

4. Costa, C.M. da, O papel do design na transformação de desperdícios têxteis em matéria-prima, Dissertação de Mestrado em Design Industrial e de Produto na Faculdade de Belas Artes e Faculdade de Engenharia da Universidade do Porto, 2016, Porto.

5. CTCP - Centro Tecnológico do Calçado de Portugal, Congresso Mundial de calçados supera expectativas, 2018, [online], updated 22.05.2018, available from https://ctcp.pt/ noticias, accessed 2018-08-02.

6. CTCP - Centro Tecnológico do Calçado de Portugal, Congresso Mundial de calçados supera expectativas, 2018, [online] available from: https://www.ctcp.pt/noticias, accessed

\section{Acknowledgements}

"This work is supported by FEDER funds through the Competitivity Factors Operational Programme - COMPETE and by national funds through FCT - Foundation for Science and Technology within the scope of the project POCI01-0145-FEDER-007136".

\section{르 FCT}

2018-08-02.

7. Portuguese Soul, Alma Portuguesa - A Indústria Mais Sexy da Europa, 2018, [online] available from: http://portuguesesoul.com/, accessed 2018-08-22.

8. APICCAPS - Associação Portuguesa dos Industriais de Calçado, Componentes e Artigos de Pele e seus Sucedâneos. Plano Estratégico cluster do calçado, In Footure 2020, Edited by APICCAPS, 2013, Porto, CEGEA.

9. APICCAPS. The shoes must go on. APICCAPS - Portuguese Shoes, Designed by the future, 2016.

10. CTCP-Centro Tecnológico do Calçado de Portugal, Empresas portuguesas de calçado apostam cada vez mais em sustentabilidade, 2018, [online] available from: https://www. ctcp.pt, accessed 2018-08-02.

11. CTCP - Centro Tecnológico, Cluster do calçado investe mais do que nunca em I\&DT, 2018, [online] available from: https://www.ctcp.pt/ noticias, accessed 2018-08-02.

12. Jornal, I., Calçado ecológico. A pegada verde dos sapatos portugueses, 2018, [online] available from: https://ionline.sapo. pt/302956, accessed 2018-08-23.

13. CTCP - Centro Tecnológico do Calçado de Portugal, Softwaves lança coleção eco-friendly Green Edition, 2014, [online] available from: https://www.ctcp.pt/info/email/index.asp, accessed 2018-08-23.

14. Green Savers, Softwaves: calçado português amigo do ambiente, 2014, [online] available from: https://greensavers.sapo.pt/softwavescalcado-portugues-amigo-do-ambiente, accessed 2018-08-23. 
15. Zouri, ZOURI - Calçado eco-vegan, 2018, [online] available at: http://www.zourishoes. com/inicio.asp, accessed 2018-08-22.

16. O Norte somos nós, O Norte Somos Nós Marita Moreno - YouTube, 2018, [online] available from: https://www.youtube.com/ watch?v=560gs4AVUr0, accessed 2018-09-07.

17. Você na TV, TVI, Marita Moreno - Uso só materiais portugueses, 2018, [online] available from: http://www.tvi.iol.pt/ vocenatv/videos/uso-so-materiaisportugueses, accessed 2018-09-07.

18. Ideal \& Co, Ideal \& Co - Living Heritage, Portuguese Handcrafted Leather Goods, 2018, [online] available from: https://www. idealandco.com/, accessed 2018-09-07.
19. Oliveira, V.Á. de, Ideal \& Co, Living Heritage, Umbigo Magazine, 2018, [online] available from: http://umbigomagazine.com/ um/2013-06-26/ideal-co-living-heritage. html, accessed 2018-09-07.

(C) 2019 by the author(s). Published by INCDTPICPI, Bucharest, RO. This is an open access article distributed under the terms and conditions of the Creative Commons Attribution license (http://creativecommons.org/licenses/by/4.0/). 